\title{
Men of the Troops: The Construction of Masculinity in the Contemporary Hollywood War Movie The Yellow Birds (2017)
}

\author{
$1^{\text {st }}$ Destia Nur Arafah \\ English Studies Program, Faculty of \\ Humanities \\ Universitas Indonesia \\ Depok, Indonesia \\ destia.arafah@gmail.com
}

\author{
$2^{\text {nd }}$ Bayu Kristianto* \\ Literature Department, Faculty of \\ Humanities \\ Universitas Indonesia \\ Depok, Indonesia \\ baladewabayu@gmail.com
}

\begin{abstract}
Various studies have noted a recent shift in the representation of masculinity in war movies, in which the image of the traditional, ideal masculine soldier has gradually been replaced by a more feminine image. One recent war film, The Yellow Birds (2017), challenges the notion of hegemonic military masculinity. This paper analyzes the movie's construction and representation of masculinity by examining its explicit and implicit elements, including symbols, cinematic imagery, character development, and dialog. It demonstrates that the movie contests hegemonic military masculinity by humanizing the main characters, criticizing the military institution, and presenting the characters as victims of the imposition of military masculinity upon them.
\end{abstract}

Keywords-war movie, masculinity, hegemonic masculinity, military masculinity, The Yellow Birds

\section{Introduction}

"Men are not born; they are made." This line, stated by Kimmel and Messner [1], characterizes society's construction of the idea of becoming a "man." Through decades of exposure to the idea of stereotypical, traditional masculinity in the media and movies, people have come to believe that to become a true man, one must act aggressively or have a strong, muscular body. Most people are probably unaware of the extent to which their concept of an idealized combatant may have been influenced by Hollywood war movies, which, according to Sitter [2], assist in prolonging and promoting the culture of hegemonic masculinity by portraying idealized men through the military's image of fearless and violent soldiers.

Considerable research has been conducted on masculinity in Hollywood war movies. Chapin, Mendoza-Burcham, and Pierce [3] stated that Hollywood has dramatized war battles and misrepresented soldiers as "overly macho, ignorant, uneducated racists" who are "addicted to killing and devoid of human emotions" (p. 84). The depiction of military masculinity in war movies has undergone a gradual shift since World War II, from the hypermasculinized ideal soldier to more fragile characterizations. Deese [4], who compared Patton (1970), Platoon (1986), and The Hurt Locker (2008), found that the notion of hypermasculinity seemed to have been revived in the most recent of these productions. Taking a different approach, Buchalski [6] found that modern war films focus on the military systems that punish subordinate masculinities.
Despite the growing amount of research, no study thus far has thoroughly considered hegemonic military masculinity in The Yellow Birds (2017), the focus of the present paper. Most movie reviews and critiques have viewed this film as a standard anti-war drama that focuses on the negative impacts war can leave with soldiers after they return home [7, 8, 9]. Hull [10] conducted a comparative study of The Yellow Birds and Platoon, focusing on their narrative structure by using four "throughlines": main character, influence character, relationship story, and overall story. One similarity that Hull found from examining the throughlines is that the main characters in both movies are stuck in a certain situation, namely a conflict created by war, and struggle with their manner of thinking about the situation.

The Yellow Birds describes the struggles and hardships of a 20-year-old man, Brandon Bartle, who fought as a soldier in the Iraq war. In this paper, we consider how The Yellow Birds, as a contemporary war movie, portrays and constructs masculinity through its primary soldier characters-Bartle, Murphy, and Sergeant Sterling. We seek to shed new light on the topic of masculinity, especially hegemonic military masculinity, as presented in war movies. Our analysis includes the application of cinematic devices, the use of language in certain dialogs, and actions taken by or affecting the selected characters.

\section{Results and Discussion}

\section{A. Humanizing the Soldiers: A Portrayal of Fragile,}

Imperfect Soldiers and a Dysfunctional Military

In the military institution, physical features and stoicism - a philosophy that highlights the importance of self-sufficiency, self-control, and emotional detachment from one's surroundings $[11,12]$ —are important in identifying a good and capable soldier. Service members train strenuously and rigorously to develop a "physically able and fit body" that can handle the physical demands of the military. Aggressiveness is viewed as a positive trait, and emotions should be suppressed since "complaining is bad" $[13,14]$. Offering a more progressive viewpoint, The Yellow Birds challenges these beliefs by humanizing its soldier characters. It does so through an emphasis on the soldiers' skills rather than their physical appearance, highlighting the characters' emotional struggles, and providing a critique of the military institution itself. 
In one scene of The Yellow Birds, Sergeant Sterling questions Daniel Murphy, his subordinate, regarding two physical attributes, his height and running speed (00:05:4700:05:55). The scene implies that physical features are important in the military. According to David and Brannon [15], the constructed idea of an "ideal soldier" involves certain characteristics, such as being "well-built, whiteskinned, and coming from the middle class." In the movie, most of the soldiers (including Murphy) are white, and the privilege of being white, or what is perceived as the superior race, is often referenced as men exercise their masculinity [16]. Although Murphy is portrayed as a white, middle-class soldier, he fails to possess the desired "well-built" body, which is a valued trait among the soldiers, and is degraded by Sterling as a "little man" (00:06:00).

Despite this deficiency, however, Murphy is a skilled shooter, as shown through Sterling's reaction to his demonstration of this ability. After the camera shows Murphy successfully hitting a target twice, Sterling immediately stops him and orders Brandon Bartle, another private acquainted with Murphy, to switch positions with him (00:05:24-00:05:39). As the scene continues, Sterling's view of Murphy seems to become more positive as he assigns Murphy to "run for him when he needs help" (00:06:02-00:06:04). Moreover, when Murphy and the squad are attacked while scouting in a real combat situation, he runs faster than the rest of the group toward the building from which the enemies are shooting (00:24:00-00:24:12) and manages to shoot one of two attackers from a considerable distance $(00: 24: 34-00: 24: 37)$. Thus we see that a soldier can be capable and skilled despite some physical flaws.

Murphy can also be viewed as the antithesis of the stereotypical "sturdy oak" soldier, a term coined by David and Brannon [15] to capture the dimension of "inexpressiveness and independence" in manhood. Compared to Bartle and other soldier characters, Murphy is more sentimental and open to expressing his emotions, sharing his worries and fears concerning the war. In one scene after a fierce shooting battle, Murphy blurts out his thoughts about the death of Vasquez, one of their companions: "You know, I was just happy it wasn't me [who died]; that's the first thing I thought. That's fucking crazy, isn't it?" (00:27:31-00:27:39). Murphy does not restrain himself from expressing, to Bartle and by extension to the audience, his guilt over feeling grateful that his comrade had died rather than himself. Moreover, Bartle does not respond to this emotional comment with any type of insult. Instead, Bartle reassures him that "what's crazy is not thinking about that shit" (00:27:40). Bartle's dialog implies that having emotions is necessary to maintain one's balance in surroundings full of danger and conflict.

Contrary to this dialog, however, Bartle is presented as a seemingly stoic character who rarely expresses his emotions and seems to follow any order given by his superiors. Nevertheless, the film uses water symbolism to reveal Bartle's emotional struggles. Water symbols appear three times in the movie: at the very beginning, in the middle, and near the end. In many cultures or religions, water carries a variety of meanings depending on its type and context. It can symbolize life, purity, flow of time, and even destruction. Generally, however, water signifies the unconscious, and films often use this symbol to elicit emotions and represent human desires and dreams [17, 18]. Therefore, the surface of water symbolizes the dividing line between one's consciousness and the unconscious realm. Furthermore, water is often used purposefully to represent one's psychological state and serve as a "host" for certain crucial events, such as loss and trauma [17].

The swift stream in the opening scene of The Yellow Birds, the dark forest river in the middle of the movie, and the desert river at the end-with Bartle present in all three scenes - seem to represent Bartle's emotional turmoil and his struggle to keep his conscious feelings at bay. The scene in which Bartle, Sterling, and a local old man dispose of Murphy's body in the desert stream is especially significant, as it happens in the midst of war. Bartle is the only person who actually immerses Murphy's body underwater as he carries it into the river, seemingly at a loss for words (1:22:16). Bartle's outward appearance, with his body surrounded by water, suggests that as a soldier he has been struggling emotionally, due to having to remain a "sturdy oak" by keeping his emotions to himself. These water-related scenes show that Bartle is not completely emotionless despite being portrayed as a stoic soldier. Although not explicitly, the movie uses water imagery to undermine the stereotype of the apathetic soldier and illustrate Bartle's emotional state.

In the movie, Christianity seems to be prominent in the military institution, as shown by several references to the Bible and the act of baptism that occurs at the base camp (00:44:11-00:44:35). In one scene, Sterling invokes a Bible verse in which God curses the land of His enemies, as he throws salt on the burned-over ground (00:21:21). This action strongly suggests that Sterling is quoting the Bible to his own and the United States' advantage, justifying their role in occupying and dispensing God's justice in Iraq. As one commander states, "This is the land where Jonah was buried, where he begged God's justice to come. And we are, we are that justice" (00:19:08-00:19:20).

In the baptism scene, a soldier is immersed in and rises from the water. Baptism may serve as a symbolic expression of God's forgiveness and acceptance through the cleansing of the body and inner being from impurity. It recalls Jesus Christ's death and resurrection and embodies the individual's "death to sin" and rising as a new and better person [19, 20, 21]. Bartle engages in a process akin to baptism when he immerses himself in the desert stream, and also in the forest stream after he returns home (00:51:54-00:53:35). He is subconsciously attempting to bury the sins he has committed while in the military, as he realizes that he has sinned because he was responsible for Murphy's disappearance and cannot assuage his guilt feelings toward Murphy's mother, to whom he had given a promise to protect Murphy. Nonetheless, his attempt to purge his past fails as when he drowns himself, an image of his old, soldier self flashes by (00:53:48-00:53:58). This scene further emphasizes Bartle's struggle as a soldier affected by the harsh military experience. Again, we see the humanization of soldier characters through the discovery that Murphy and Bartle's characters are not in accord with the generally accepted military standard of masculinity. 
Besides disclosing Bartle's and Murphy's physical and emotional struggles in the military, the movie also attempts to challenge hegemonic military masculinity by revising the misconception that joining the military is a necessary rite of passage to manhood. In American society, the melodramatic portrayal of the "good American warrior" and its relationship with masculinity frequently provided a role model to young men, leading them to join the military and become combatants as a way of achieving a state of manhood [1]. In the movie, Murphy tells Bartle that his father "was in the Marines" (00:06:34). This is a common trope in war movies in which a young man joins the military out of family tradition, following his father and/or grandfather's steps "with a romanticized ideal of what makes a man a man" [6]. However, the movie alters this misconception as Murphy explains to Bartle that he just wants "to do something good before I do whatever else it is I'm gonna do" (00:06:41). On the other hand, Bartle, who was unable to continue his education and "wound up fucking around," explains that he is unsure whether joining the military feels like "a good thing," but he later says that it is a "thing to do" (00:06:5800:07:17). The dialog implies that both men have their own reasons, unrelated to proving their manhood or gaining status as "men," to join the military.

The movie continues to amend the standard military narrative by portraying the military as a "dysfunctional" institution that demasculinizes its members. On the day when the troops prepare for a strike against the enemy, Bartle responds bitterly to an interviewer who asks him if the day is "the most important day of your life" by retorting, "I fucking hope not" (00:19:44-00:19:50). Murphy expresses similar sentiments on another occasion, telling Bartle, "I'm never gonna tell anybody I was here when I get back. ... I'm gonna get a place to myself ... and let my fucking hair grow back out" (00:46:24).

This comment by Murphy contradicts his behavior in an earlier scene, when he asked to borrow a razor so that he could shave his head (00:08:30). The shaved-head appearance is renowned in "traditionally masculine professions," such as the military, for presenting a tough look and symbolizing aggression, dominance, and confidence [22, 23]. Murphy's desire to grow his hair back implies a willingness to lose idealized masculine traits in order to be free from the limitations and burdens imposed by the rigorous training and violent actions in which he participates as a soldier. He ends his comment by saying that he does not "want this [the military job] to be a part of me" while shedding a tear (00:47:14). Clearly, Murphy is experiencing a deep sense of devastation, very different from his initial expectations, due to his exposure to a real combat situation.

Peebles (2011) described the emergence of feelings of powerlessness as the result of differences between soldiers' expectations and their actual experiences of combat (as cited in Buchalski, 2013, p. 53) [6]. Losing a military medic whom he adored (00:47:57-00:49:26) further drives Murphy into depression and causes him to lose his focus and sense of hope; as a result, Murphy distances himself from Bartle and the rest of the troops. Bartle and Murphy's exposition of such negative reactions toward the military can be seen as a form of "demasculinization" or "renegotiations of masculinity," as it demonstrates the inefficiency of the military's formation of soldiers and of its indoctrination of masculinity [6].

\section{B. Two Sides of a Coin: The Movie as a Critique of Hegemonic Military Masculinity}

By portraying the primary two young soldier characters with all their flaws relative to the military's standard of masculinity, The Yellow Birds draws our attention to the concept of a "new man"- a somehow "feminized" man who openly feels emotions. Interestingly, the movie continues to challenge hegemonic military masculinity by criticizing this very notion through the actions of Sterling, a complex character, and through Murphy's death.

Hegemonic masculinity, as defined by Connell (1987), concerns men's dominance not only over women but also over other men (as cited in Demetriou, 2001, p. 341) [24]. To accomplish this dominance, men can use various strategies, one of which is to exploit language to degrade or emasculate others, since language can be used to express or belittle characteristics such as gender, identity, power, class, status, and age [25]. In an early scene, Sterling refers to Murphy as "little man" due to his height (00:06:00). Soldiers commonly engage in such mocking, harassing, or discriminatory language to express disgust for the enemy or to belittle fellow soldiers; such use of language, unfortunately, is "taken for granted" and not questioned by the institution (Holmgren, n.d, p. 26). In the same scene, Sterling directly appoints Murphy to accompany and support Bartle in battle, yet he insults him by referring to him as Bartle's "girlfriend" (00:06:06-00:06:16). Goldstein [26] argued that feminization within the military institution targets not only enemy troops and civilians, but also non-combatants and subordinates within one's own forces, who are perceived as feminine within the military. He added that because of the absence of actual females within the military, the subordinate males then "take on feminine gender," such as "girls" or "pussies" (p. 356). In a hypermasculinized environment that despises weakness and equates it with femininity, subordinate soldiers often end up displaying attributes of the feminine gender imposed on them by their superiors.

Sterling's action when he discovers Murphy's dead body might seem at first to perpetuate hegemonic military masculinity, yet in fact it is the opposite. Sterling and Bartle search for Murphy after he leaves the patrolling troop without a trace, and with the help of a local man, they find his dead body (1:16:02-1:17:28). Sterling initially intends to retrieve Murphy's corpse and take it back to the base, but he changes his mind after Bartle says that they cannot take the corpse back in such terrible condition. He orders Bartle to "go get the Hajj with the cart" and forces him to conceal the discovery. Instead, he decides to get rid of the corpse, saying that "we need to fix it like it never happened," and they dispose of Murphy's body in the nearest stream (1:18:20$1: 22: 35)$. After that, Sterling proceeds to shoot the old man in the head to get rid of a witness (1:23:35).

Sterling's actions of feminizing his subordinate Murphy, deciding to not retrieve Murphy's body properly, and shooting an old man in cold blood may be seen as a reinforcement of hegemonic military masculinity. However, the scene actually embodies a critique of masculinity. In addition to maintaining a fit body, soldiers are also required to exhibit self-control and to be capable of concealing their emotions, since emotionality is seen as a weakness and expressing one's emotions openly in the context of combat could be fatal. As a result, soldiers tend to mask their 
feelings of fear in order to survive [27]. This phenomenon of "mask-culinity" occurs to Sergeant Sterling as an impact of a reinforcement of masculinity by the military institution. After Sterling and Bartle have returned from Iraq, the Criminal Investigation Division (CID) pursues them for information concerning Murphy's mysterious disappearance. In one scene, Sterling exclaims in a conversation with Captain Anderson of the CID that he "ain't a coward" and "ain't running" (00:37:46-00:38:14). However, his words prove to be merely an attempt to quell his anxiety and guilt, as Sterling eventually decides to commit suicide (00:59:13), which can be perceived as the ultimate act of despair [28]. This decision to end his life while under investigation by the CID and while presumably wracked by guilt shows that Sterling is as tattered and fragile as Bartle and Murphy, despite his portrayal as a masculine soldier in combat. As a soldier possessing a higher rank, he must act tough to maintain his power in the military. He masks his own fear and weakness to survive in the hypermasculinized military environment by feminizing other characters and acting violently. But ultimately, his concealed distress leads him to take his own life.

Near the end of the movie, the audience learns that Murphy was abducted by mysterious figures after he aimlessly left the troop $(1: 17: 55-1: 18: 10)$. Eventually, his body was discovered in a hideous, castrated state. As explained above, Murphy is portrayed as a sensitive, emotional soldier with characteristics that contradict the qualities valued by hegemonic military masculinity. His death, then, is in accordance with Sitter's argument [2] that subordinate characters in war movies apparently get "the least noble death scenes," as opposed to the "ideal male figure" who experiences "the most honorable deaths" (p. 130). Furthermore, the act of castration by Murphy's abductors represents his emasculation at the hands of other men. According to the Online Oxford Dictionary, castration can be defined as "the state of being deprived of power, vitality, or vigor" [29]. Historically speaking, the use of castration by a conqueror, especially if performed on corpses after death, carries a symbolic meaning of taking away enemies' manhood and power [26]. Thus, the posthumous castration of Murphy, while evidently a form of violent action that signifies aggressiveness in the realm of combat, is also a symbolic form of feminization, further reinforcing the impression that a man or soldier with "feminine" qualities cannot survive in a punitive, masculinized world.

However, based on the previous explanations about Murphy's devastation, the scene also portrays a deeper meaning, revealing the fact that "the military is not for everyone" [6]. Like Sterling, a tragic victim of "maskculinity," Murphy is also negatively affected by the ideology of military masculinity, which results in him losing his senses, going astray, and being killed. The fates of the three main soldier characters vary, but the enforced idea of military masculinity causes harmful and destructive effects for all of them.

\section{Conlusions}

Through its use of symbols, language, cinematic imagery, dialog, and the characters' actions, The Yellow Birds effectively challenges and critiques the notion of hegemonic military masculinity. First, it displays a progressive view of masculinity by portraying the soldier characters as fallible and imperfect human beings with deeply felt emotions, while also criticizing the military for imposing a traditionalist notion of masculinity that is essentialist and onedimensional. The movie uses both implicit and explicit elements, such as the characters' actions and speeches and the element of water as a symbol of unconsciousness, to show the audience that soldiers have a more humane side. Finally, the movie criticizes the notion of hegemonic military masculinity by depicting its devastating impacts on soldiers who are forced to toughen up and persist so as to survive within the military institution and in a combat zone. Those impacts include Sterling's act of "masking" his weaknesses by humiliating his subordinates, his violent actions, and the horrific deaths that both Murphy and Sterling suffer.

As Hollywood continues to present, alter, and transform the idea of military masculinity through film narrativesincluding fictional movies and those based on true stories-it is important for audience members to respond critically to these presentations. The Yellow Birds skillfully criticizes a stereotype by depicting the impact on several characters of having the concept of military masculinity forced upon them. Future studies should analyze and compare contemporary war movies to see how their representation of soldier characters and the military institution embodies either development or regression in their portrayal of military masculinity.

\section{References}

[1] Karner, T. (1998). Engendering violent men: Oral histories of military masculinity. In masculinities and violence (pp. 197-232). University of Houston Libraries.

[2] Sitter, M. (July, 2012). Violence and masculinity in Hollywood war films during World War II. Thunder Bay, Ontario: Lakehead University.

[3] Chapin, J., Mendoza-Burcham, M., \& Pierce, M. (2017). Third-force influences: Hollywood's war films. Retrieved from http://strategicstudiesinstitute.army.mil/pubs/parameters/Issues/Autu mn_2017/10_ChapinMendoza-BurchamPierce.pdf.

[4] Deese, M. (2010). "Do You Know Why I Am The Way I Am?" A study of masculinity in war films. Journal of Undergraduate Research, XIII. Retrieved from https://www.uwlax.edu/urc/juronline/PDF/2010/deese.CST.pdf.

[5] Alorda, M. I. (June 26, 2013). Masculinity and violence in 21stcentury U.S. film: 'A History of Violence' and 'Drive'. Spain: University of the Balearic Islands.

[6] Buchalski, T. T. (January 01, 2013). The faces of war: Representing warrior archetypes, masculinity, and race in modern war films. United States: University of Colorado.

[7] Grierson, T. (2017). 'The Yellow Birds': Sundance review. Retrieved from https://www.screendaily.com/reviews/the-yellow-birdssundance-review/5114017.article.

[8] Passantino, M. (2018). The Yellow Birds. Retrieved from http://www.undertheradarmag.com/reviews/the_yellow_birds/.

[9] Shannon, G. (2018). The Yellow Birds movie review: An inoffensive but redundant mess. Retrieved from https://www.theyoungfolks.com/film/121890/the-yellow-birds-moviereview-an-inoffensive-but-redundant-mess/.

[10] Hull, J. (2018). The Yellow Birds. Retrieved from https://narrativefirst.com/analysis/the-yellow-birds

[11] Biondi, C. (2007). Stoicism and the military. Democratiya 11, 67 76. Retrieved from https://www.dissentmagazine.org/wpcontent/files_mf/1389820789d11Biondi.pdf.

[12] Grigorescu, L. (February 20, 2009). Camouflaged emotions stoicism in the military. Retrieved from https://apps.dtic.mil/dtic/tr/fulltext/u2/a513812.pdf. 
[13] Hinojosa, R. (2010). Doing hegemony: Military, men, and constructing a hegemonic masculinity. The Journal of Men's Studies 18 (2), 179 - 194. The Men's Studies Press.

[14] Hockey, J. (2003). No more heroes: Masculinity in the infantry. In the criminology of war (pp. 401 - 410). London: Routledge. pp. 15-16

[15] Locke, B. (n.d.). The military-masculinity complex: Hegemonic masculinity and the United States armed forces. Retrieved from http://brandontlocke.com/projects/militarymasculinitycomplex/index. html.

[16] Epstein, D. (2011). Marked men: Whiteness and masculinity. Agenda 14 (37), 49 - 59. United Kingdom: Taylor and Francis. pp. 53-54

[17] D'Aloia, A. (2012). Film in depth: Water and immersivity in the contemporary film experience. Acta Univ. Spaientiae, Film and Media Studies 5, 87 - 106. Milan: Università Cattolica del Sacro Cuore.

[18] Sue B. (2018). Dreaming of water: What does it really mean?. Retrieved from https://exemplore.com/dreams/Dreaming-of-WaterThe-Meaning-of-Water-in-Dreams.

[19] Battle, J. A. (February 2007). The significance of the mode of baptism. WRS Journal 14 (1), 9 - 20. Retrieved from http://wrs.edu/Materials_for_Web_Site/Journals/14-1_Feb2007/Battle-Mode_Baptism.pdf.

[20] Martin, H. (n.d.). Baptism as cleansing. Retrieved from https://biblicalstudies.org.uk/pdf/bq/16-8_378.pdf.

[21] Robertson, A. T. (n.d.). Baptism. Retrieved from http://christianbeliefs.org/articles/Baptism\%20\%20A.\%20T.\%20Robertson.pdf.
[22] Mannes, A. E. (2012). Shorn scalps and perceptions of male dominance. Social Pyshcological and Personality Science 00 (0), 1-8. doi: 10.1177/1948550612449490.

[23] Pappas, S. (October 5, 2012). The power cut: Men with shaved heads look more dominant. Retrieved from https://www.livescience.com/23766-shaved-head-dominant.html.

[24] Demetriou, D. Z. (2001). Connel's concept of hegemonic masculinity: A critique. Theory and Society 30, 337 - 361. Netherlands: Kluwer Academic Publishers.

[25] Ifechelobi, C., \& Ifechelobi, J. N. (December, 2017). Gender discrimination: An analysis of the language of derogation. Journal of Humanities and Social Science 22 (12), 23-27. Retrieved from http://www.iosrjournals.org/iosrjhss/papers/Vol.\%2022\%20Issue12/Version-6/E2212062327.pdf.

[26] Goldstein, J. (2001). War and gender: How gender shapes the war system and vice versa. Cambridge University Press.

[27] Trenholm, J., Olsson, P., Blomqvist, M., Ahlberg, B. M. (2013). Constructing soldiers from boys in Eastern Democratic Republic of Congo. Men and Masculinities 00 (0), 1 - 25. doi: 10.1177/1097184X12470113.

[28] White, M. D. (May 12, 2010). Can suicide be meaningful?. Retrieved from https://www.psychologytoday.com/us/blog/maybe-its-justme/201005/can-suicide-be-meaningful.

[29] Castration. (n.d.). In English Oxford living dictionaries. Retrieved from https://en.oxforddictionaries.com/definition/castration. 